\title{
Engaging Landscapes, Connecting Provinces: Milestones and the Construction of Hispania at the Beginning of the Empire
}

\author{
Sergio España-Chamorro
}

Introduction ${ }^{1}$

At the time of Augustus, the reconfiguration of the administrative system of Hispania was combined with a new plan for interconnectivity. ${ }^{2}$ The foundation of Augusta Emerita (Mérida) in Lusitania required to restructure the former regional system therewith implementing a new provincial system of communication. With the redefinition of the border between Hispania Citerior and the newly created province of Baetica, it was necessary to reorganise the administration of roads of the recently created provinces. Furthermore, a new conception of administrative unity was created. It was traceable by milestones, as will become clear in the below presented example of the so called Ianus Augustus. These significant processes transformed the republican provinces (Hispania Ulterior and Hispania Citerior) into a new provincial system consisting of three parts instead of two, the subdivision of Hispania Ulterior into Baetica and Lusitania and the territorial redefinition of Hispania Citerior Tarraconensis, hitherto called only Citerior. The new territories incorporated into Hispania Citerior (the north-western corner of the Iberian Peninsula) required the implementation of a system of highways to connect the new cities founded by Augustus after the Cantabrian Wars and to bring the Roman administration system to the region. ${ }^{3}$ The impact of this reorganisation can be

1 This research was funded by the I+D Proyect "Carmina Latina Epigraphica" (MINECO Ref. PGC2018-095981-B-Ioo), "Identidades norteafricanas en transformación" (MINECO Ref. PID2019-107176GB-Ioo), the IdEx project at the Institut Ausonius (Bordeaux), and the Juan de la Cierva Incorporación contract (Madrid).

2 I am aware that in Anglo-Saxon tradition the term "Spain" is more frequently used, but I prefer to omit this expression because this is a modern concept that should be avoided for the Roman period. Terms like Iberian Peninsula or the Latin Hispania are more accurate and allow to include the region of modern Portugal.

3 A. Kolb, 'The conception and practice of Roman rule: the example of transport infrastructure', GeorgAnt 20 (2011-2012), 53. She says that Roman road policy has been considered one of the best strategies for opening and developing conquered territories. 
traced through road epigraphy. Republican milestones have only been documented in the Northeast of the Iberian Peninsula. However, the opening of new roads and the creation of the new provinces brought the habit of road epigraphy to other areas. Through a careful analysis of the Julio-Claudian milestones, the administrative policy in rural areas can be traced.

\section{Landscape Archaeology and Political Landscapes: An Introduction}

Landscape Archaeology has been developed as a strong sub-discipline for giving a wider idea of Antiquity outside of the urban environments. ${ }^{4}$ Tilley provided a fantastic idea of what is a landscape, saying that it is not only as a conjunction of visible, tangible and available elements, but also a construction of a system of meaning and its symbolic aspects, ${ }^{5}$ which reflect and integrate multiple factors (social, economic, historical, political, ideological ...). The political involvement is the part I will develop in this paper connecting it with the administrative implications. This offers an interesting new vision of the beginning of Roman infrastructure planning in the Iberian Peninsula by analysing inscriptions connected with the roads.

Focusing on the administrative epigraphic evidence, milestones and termini have even more links with the geographical context than other kinds of epigraphy due to the fact that the main purpose is to inform walkers about any aspect of the surrounding landscape. Taking into account this point of view, it is important to understand some aspects of road inscriptions. Of course, it is important to study and to analyse their inscribed texts, but the above mentioned new approaches of landscape archaeology have demonstrated the importance of their symbolism narrowly linked with the territory and the way of their dispersion in order to have a wider vision of these general phenomena. It also has opened a huge range of possibilities of interpretation. Linking landscape and politics allows us to know which areas were important for Imperial propaganda and to understand the pedagogy of power. The new administration created by Augustus changed the political landscape of the whole Iberian Peninsula. The first emperor founded new Roman coloniae that became very important points for spreading the Roman culture and lifestyle. These new

4 This is a vast topic, for which see in this volume the contributions by Marietta Horster and Günther Schörner. I expand on the theoretical framework and my personal position in my unpublished thesis: S. España-Chamorro, Límites y territorios de la Bética romana (Madrid 2017), 1-53.

5 C. Tilley, Interpretative Archaeology (Providence 1993); C. Tilley, A Phenomenology of Landscapes. Places, Paths and Monuments (Berg 1994). 
colonies and some other already existing cities were used as administrative capitals of provinces or of conventus iuridici. ${ }^{6}$ This allowed him to rethink the whole provincial infrastructure and roads around them. Roads were an important part of rural propaganda and they were commissioned by the Imperial house. The various roads can be distinguished by main characteristics: their quality, their durability, their pavement into the entrance area of the cities, as well as by bridges and other annexed infrastructures. Directing to the horizon, roads overpassed the irregularities of territories. ${ }^{7}$ This was a strong symbol of connectivity of the Hispanic provinces with the Roman empire outside the peninsula, but at the same time a way of representing the subjugation and the new Roman order by establishing an orthogonal division of land and territories. ${ }^{8}$ It reminded the inhabitants of the evident military character of roads with the inclusion of the name of the legions working on the public infrastructure into the inscribed text, ${ }^{9}$ or the inclusion of military adjectives in these inscriptions as for example, the via Augusta militaris mentioned in some Baetican milestones from Domitian. ${ }^{10}$ Milestones and other road inscription were a perfect way for the Romans to engage in the new provincial landscapes and to develop public epigraphy in rural areas. This serial epigraphic source outside the city brought the Imperial power to the margins of the cities. ${ }^{11}$

6 About this form of administration, M.D. Dopico Caínzos, 'Los conventus iuridici: origen, cronología y naturaleza histórica', Gerión 4 (1986), 265-283 and P. Ozcáriz Gil, Los conventus de la Hispania Citerior (Madrid 2006).

7 S. España-Chamorro, 'Pedagogía del poder imperial en el espacio rural bético a través de los miliarios', Potestas 10 (2017), 31-48.

8 P. Zanker, 'The city as a symbol: Rome and the creation of an urban image', in E. Fentress and S.E. Alcock (eds.), Romanization and the City: Creation, Transformation, and Failures. Proceedings of a Conference Held at the American Academy in Rome to Celebrate the 5oth Anniversary of the Excavation of Cosa, 14-16 May, 1998 (Portsmouth [RI] 2000), 29.

Legio IIII Macedonica in Las Cinco Villas area, CIL XVII/1, 169-17o. I. Moreno Gallo, Item a Caesarea Augusta Beneharno. La carretera romana de Zaragoza al Bearn (Zaragoza 2009), 39-43; J. Andreu Pintado, 'La ciudad romana de Los Bañales (Uncastillo, Zaragoza) en las fuentes históricas', in J. Andreu Pintado (ed.), La ciudad romana de Los Bañales (Uncastillo and Zaragoza) entre la historia, la arqueología y la historiografía (Zaragoza 2012), 19-100, esp. 34-37.

10 Four milestones: $C M B$ I $27=C I L \mathrm{II}^{2} / 5$, p. 65, n. $10=C I L \mathrm{II}^{2} / 7$, p. 65, n. 15 ; $C M B$ I $28=C I L$ II $4721=C I L \mathrm{II}^{2} / 7$, p. 66, n. 30; $C M B$ I $29=C I L$ II $4722=C I L \mathrm{II}^{2} / 7$, p. 66, n. 31; $C M B$ I $30=C I L$ II 4703. The abbreviation Baeticae. Miliarios y política viaria en la Hispania Ulterior Baetica en época imperial (s. IIV)', Archeologia Classica 70 (2019), 397-454; see also P. Sillières, 'La vehiculatio (ou cursus publicus) et les Militares Viae. Le contrôle politique et administratif de l'Empire par Auguste', SHHA 32 (2014), 123-141.

11 España-Chamorro 2017, op. cit. (n. 6), 31-48; S. España-Chamorro, 'Poder y Territorio. La política territorial y viaria en la Baetica de Augusto a Adriano', in A.J. Domínguez et al., 
The Roman transport system was a fundamental tool for the consolidation of the newly annexed territories and for the dissemination of the territorial administration, the culture of Roman power, and the Roman lifestyle. ${ }^{12}$ It was also one of the best ways to incorporate these territories into the economic framework of the Roman empire and the provinces. However, the cases of the Iberian Peninsula are inconsistent within the empire since Rome did not create a new road system from scratch (quite the opposite), but relied heavily on the pre-Roman communication and territorial systems..$^{13}$ The first road regulation known is the lex Sempronia viaria implemented by Caius Gracchus and dating back to BCE $123 .{ }^{14}$ This law was also the first to consider milestone policy, thus contrasting with the (much earlier) epigraphic habit represented in some republican milestones. In this sense and connected with the use of the mile, standardised in Republican times, Gianfrotta proposed that this lex belonged to the agrarian reform effectuated in Italy in which the Roman mile was legally sanctioned as the official measure for the Roman road policy.15

Republican milestones have recently been compiled in a corpus that provides a useful image of how concentrated their use was during the Republic. ${ }^{16}$ Only 50 republican milestones are known to date. ${ }^{17}$ These are concentrated in few regions: in Italy, Southern Gaul to the Hispanic region (between the

Formas, manifestaciones y estructuras del poder político en el Mundo Antiguo (Madrid 2017), 333-350.

12 España Chamorro 2019, op. cit. (n. 9).

13 Some interesting historical notes can be found in Timeus of Tauromenium in, De mirab. Ausc. 85 where he explains that the path from Italy to the Iberians was called the "via Herculea", later known as "via Augusta" after the reformulation of its name, which makes it obvious that both viae, Heraclea and Augusta, refer to the same road; cf. Pol. 3.39; Str. 3.4.9 with an extensive description of this road.

14 C. Campedelli, L'amministrazione municipale delle strade romane in Italia (Bonn 2014).

15 P.A. Gianfrotta, Le vie di comunicazione, in A. Schiavone and E. Gabba (eds.), Storia di Roma IV. Carattere e Morfologia (Rome 1982), 303. The connection of road and agrarian policies can also be seen in BCE 223, when the via Flaminia was constructed and the lex Flaminia de agro Gallico e Piceno viritim dividundo was enacted, see V. Ponte Arrébola, 'Régimen jurídico de las vías romanas', in I. Moreno (ed.), Las técnicas y las construcciones en la ingeniería romana (Córdoba 2010), 84.

16 B. Díaz Ariño, Miliarios romanos de época republicana (Rome 2015).

17 Diaz Ariño 2015, op. cit. (n. 15) published 48 republican milestones, but recently published papers have added some more: A. Buonopane and C. Gabrielli, 'I due miliari repubblicani della via Faesulae-Pisae e la viabilità nell'Etruria settentrionale', Sylloge epigraphica Barcinonensis 16 (2018), 213-224 and A. Buonopane and C. Gabrielli, 'Miliari e viabilità dell'Etruria romana: un aggiornamento e alcune considerazioni', in A. Kolb (ed.), Roman Roads. New Evidence - New Perspectives (Berlin and Boston 2019), 375-403. 
rivers Rhodanus/Rhône and the Hiberus/Ebro) and the eastern provinces of Macedonia and Asia. Other areas that were conquered during the Republic such as Africa or the southern part of Hispania Ulterior, the future Baetica, have not provided any republican milestone. It is astonishing that later, during the Imperial period, the provinces Africa and Baetica will have such a rich repertoire and great number of Latin inscriptions. In some areas such as the Ebro and Guadalquivir valleys or the Eastern coast of the Iberian Peninsula, the public epigraphic habit started to develop slowly from the second century BCE onwards. We know from archaeology and classical text sources that the road system of these provinces was already partially constructed and working before that date. The situation in the empire outside Hispania is also quite complex and diverse. Until now, around 8000 milestones are documented. ${ }^{18}$ It is assumed that less than $5 \%$ of all milestones were erected in the republican times. The numbers of stones known from the provinces differ in absolute numbers, and it seems in proportion to the antique milestones, depending on the later history of the region and its respective infrastructure: Published are 112 milestones of Britannia, 250 of the Narbonensis, 450 of Palaestina, 570 of the provinces in the Illyricum, more than 1000 in Asia Minor and around 2300 in Africa Proconsularis and Numidia. Focusing on a specific geographical area like Hispania, we find 79 milestones in Baetica, ${ }^{19}$ around $45^{-}-500$ in Lusitania ${ }^{20}$ and around 639 in Hispania Citerior. ${ }^{21}$

Assuming that no major events and economic developments in Portugal and Spain had an impact on the preservation of the stones, this data apparently shows us that there were different policies of road management. Provinces or conventus iuridici had the control and maintenance of the viae publicae. This created differences in the epigraphic habit of each administrative unit.

18 A. Kolb, 'Miliaria: Ricerca e metodi. L'identificazione delle petre milari', in F. Pavan (ed.), I miliari lungo le strade dell'impero. Atti del Convegno (Isola della Scala, 28 novembre 2010) (Verona 2011), 19; A. Kolb, 'Via ducta - Roman road building: An introduction to its significance, the sources and the state of research', in Kolb 2019, op. cit. (n. 16), 3; Epigraphik-Datenbank Clauss/Slaby (EDCS) provides a total number of 7919 .

19 España Chamorro 2019, op. cit. (n. 9).

20 EDCS (July 2020) presents only 250 milestones, as well as M. Rathmann, 'Miliaria in der Provinz Lusitiania', in Kolb 2019, op. cit. (n. 16), 303-323 (with and without inscriptions), probably taking only the information from EDCs; this will be updated in the corpus that E. Paredes Martín and I are preparing together (Corpus Milliariorum Lusitaniae) under development and the total number will increase it at least until $45^{\circ}-500$ (including anepigraphic milestones).

21 Taking only into account the inscribed milestones. The total number has been reached by using the information provided in CIL XVII/1 and A. Rodríguez Colmenero et al., Miliarios e outras inscricións viarias romanas do Noroeste Hispánico (Santiago de Compostela 2004). 
Apparently, milestones were not always important for travellers in terms of movement, but was a powerful element of propaganda.

Rome and Italy were spaces in which a huge number of milestones were placed. We can see that from the Republican times onwards there is a great interest in providing useful information about distances between cities. In other parts of the empire the density of milestones is lower, or it may be that they were not set up on all larger connecting roads, but only on some particular points of the main routes.

Augustus reconsidered the whole process of communication and connectivity within the empire. In his time, a lot of roads were opened or rebuilt. He also transformed the conception of connectivity by placing the miliarium aureum in the heart of the empire, the forum of Rome, and quite close to the umbilicus urbis Romae. ${ }^{22}$ The central place of the city was next to the centre of communications of the whole empire. This element was erected only for symbolic and propagandistic purposes, but not as a functional element. According to the Digesta the point for measuring roads in Italy were the city walls, not this milestone. ${ }^{23}$

Augustus implemented and reinforced the propagandistic function of road epigraphy. Until his age, this element was mainly italic, as can be seen above, but knowing of the power of propaganda in rural areas, he introduced road epigraphy in new territories such as in Baetica, Lusitania or Gallia. Some of those new provincial text were written in an archaic way. The first milestones from Africa, for example, were erected by him using a traditional formula that reminds us of the republican texts. ${ }^{24}$

\section{The Augustan Administration of Hispania}

The end of the Cantabric Wars finalised the conquest of the Iberian Peninsula. It is supposed to have finished the administrative project planned by Caesar. This plan consisted in reorganising the two Republican provinces into three and its subdivision into the conventus iuridici. ${ }^{25}$ It was also a new way of reorganising the engagement amongst local communities within the empire. The foundation of new important cities such as Augusta Emerita, Asturica Augusta,

\footnotetext{
22 Plin. nat. 3.66; Tac. hist. 1.27; Suet. Otho 5; D.C. 54.8.4.

23 Mille passus non a miliario urbis sed a continentibus aedificiis numerandi sunt (Dig. 50.16.144).

24 Díaz Ariño 2015, op. cit. (n. 15).

25 This provincial subdivision specially known for Dalmatia, Asia and Hispania is quoted by Pliny. For the Hispanic provinces, Plin. nat. 3 .
} 
Bracara Augusta or Lucus Augusti, placed in an area with a low number of Latin or Roman communities, was the materialisation of this new plan. But this also entailed the renovation of the road network and its involvement with the new imperial propaganda. The implementation of Roman culture in the newly conquered areas and the restructured former provincial territories also brought about a new process of Latinization. This supposed not only the incredible rise of the epigraphy, but also the incorporation of a new brand model of inscriptions such as the generalisation of the funerary epigraphic habit, the quotation of the origo and the extinction of the Paleohispanic language with the only exception of Lusitanian. ${ }^{26} \mathrm{~A}$ new way of understanding space and of incorporating measurements in the public daily life appeared. It can be perceived with the apparition of the mensurae sepulcri with the indicatio pedaturae, termini and milestones in other areas away of the Ebro valley. ${ }^{27}$

As we can see, the beginning of imperial milestones with Augustus in the Iberian Peninsula can be linked to a wider process of Latinization and generalisation of epigraphy in cities and in rural areas. There also was a special interest in bringing the epigraphy into the rural areas.

\section{5 Where Are the Milestones? The Evidence}

There are obvious differences between the new imperial provinces:

1. In Baetica 79 milestones have been found. 25 were erected in the JulioClaudian period. 11 of them were placed in the time of Augustus. Only milestones from Caracalla's times are as numerous as in Augustus' time.

2. In Lusitania a work-in-progress compilation has compiled around 400450 milestones (around 300 with inscription). ${ }^{28}$ Only 24 inscriptions can

26 I. Simón, 'El final de las escrituras paleohispánicas', Acta Palaeohispanica XI. Palaeohispanica 13 (2013), 167-186; J. Herrera Rando, 'La desaparición de las lenguas y escrituras paleohispánicas en el sur peninsular', Antesteria 5 (2016), 153-163.

27 D. Vaquerizo Gil and S. Sánchez, 'Entre lo público y lo privado: Indicatio pedaturae en la epigrafía funeraria hispana', AEspA 81 (2008), 101-131 and the addenda in AEspA 82 (2009), 311-313. There is only one republican terminus in the whole peninsula, see Fuentes de Ebro, Zaragoza according to C. Cortés Barcena, Epigrafía en los confines de las ciudades romanas (Rome 2013), 136-137, n. 50, and 14 termini from the Augustan age (see ibid. 221-222).

28 See fn. 20. Before the compilation of that corpus, I have previously published the total number of 108 milestones based on the information of J.M. Solana Sáinz and L. Hernández Guerra, La política viaria en Hispania siglo III d.C. (Valladolid 2002); J.M. Solana Sainz and L. Sagredo San Eustaquio, La política viaria en Hispania. Siglo IV d.C. (Valladolid 1998); J.M. Solana Sainz and L. Sagredo San Eustaquio, La política viaria 
be dated in the Julio-Claudian period. The intervention of Augustus is very low with only 7 inscriptions.

3. Hispania Citerior is a much more complicated province. This is the biggest province in the whole empire. There is also a high number of epigraphic evidence in its territory. The first of two fascicles of $C I L$ XVII $/ 1$ for Spain has compiled the evidence without the Northwestern part. ${ }^{29}$ Another corpus made by a Galician team complete this information. ${ }^{30}$ We have a total number of 639 milestones. 94 are dated to the Julio-Claudian age, ${ }^{31}$ of which 35 are dated to the Augustan time.

In Baetica, 43 milestone inscriptions have been found in the main axis of the province: the via Augusta. All the Julio-Claudian inscription belonging to this road were placed in the surrounding of Corduba with the only exception of a milestone of Nero, found at El Puerto de Santa María (Cádiz), at the end of the via Augusta. ${ }^{32}$

This Neronian milestone is an important proof about the caput viae of the Baetican via Augusta. The Augustan road system fixed the new capita viarum of the provinces. Baetican milestones of the via Augusta inform us that this

en Hispania: siglos I-II d.C. (Valladolid 2008); Recently Rathmann 2019, op. cit. (n. 19) counted 250 milestones for Lusitania.

29 In $C I L \mathrm{XVII} / 1$. The total amount is 307 milestones.

30 Rodríguez Colmenero et al. 2004, op. cit. (n. 20).

31 Augustus: $C I L$ XVII /1. 9, 31, 67, 70, 73, 74, 78, 84, 86, 114-116, 118-121, 134, 135, 142, 147, 151, 169, 170, 239, 257 287; Rodríguez Colmenero et al. 2004, op. cit. (n. 20), n. 1, 55, 79, 118, 121, 133, 14O, 167, 565; Tiberius: $C I L$ XVII/1. 4, 14a, 29, 37, 143, 146, 148, 149a-b, 152, 153, 204, 209, 218, 224, 228, 230, 240, 246, 258, 278, 279, 284, 286, 288, 294, 295; Rodríguez Colmenero et al. 2004, op. cit. (n. 20), n. 2, 53, 56, 65, 76, 137, 139, 142; Caligula: Rodríguez Colmenero et al. 2004, op. cit. (n. 20), n. 208, 211; Claudius: $C I L$ XVII/1. 15, 35, 93, 94, 109, 130, 139, 289; Rodríguez Colmenero et al. 2004, op. cit. (n. 20), n. 208-211; Nero: CIL XVII/1, 110, 124, 141, 210, 219, 220; Rodríguez Colmenero et al. 2004, op. cit. (n. 20), n. 222-569.

Augustus: $C M B$ I $1=C I L$ II $4701=C I L I^{2} / 7$, p. 65 , n. 4; $C M B$ I $2=C I L$ II $4702=C I L \mathrm{II}^{2} / 7$, p. 65 , n. 6; $C M B$ I $3=C I L \mathrm{II}^{2} / 7$, p. 65 , n. $11=H E p 4,300 ; C M B$ I $4=C I L$ II $4703=C I L \mathrm{II}^{2} / 7$, p. 65 , n. 12; $C M B$ I $5=C I L$ II $4704=C I L$ II $^{2} / 7$, p. $65, \mathrm{n} .15=H E p 4$, 302; $C M B$ I $6=C I L$ II 4705 $=C I L \mathrm{II}^{2} / 7$, p. 65 , n. 17 ; $C M B$ I $7=C I L$ II $4706=C I L \mathrm{II}^{2} / 7, \mathrm{p} .65$, n. $20 ; C M B$ I $8=C I L$ II 4707 $=C I L \mathrm{II}^{2} / 7$, p. 66, n. $24=H E p$ 4, 294; $C M B$ I $9=C I L \mathrm{II} 4708=C I L \mathrm{II}^{2} / 7$, p. 66, n. $25=H E p 4$, 295; $C M B$ I $10=C I L$ II $4709 / 4710=C I L \mathrm{II}^{2} / 7$, p. 66, n. $26=H E p 4$, 296; $C M B$ I $11=C I L$ II 4711 $=C I L \mathrm{II}^{2} / 7$, p. 66, n. $27=H E p$ 4, 297; Tiberius: $C M B$ I $12=C I L$ II $4712=C I L \mathrm{II}^{2} / 7$, p. 65 , n. 5; $C M B$ I $13=C I L$ II $4713=C I L I^{2} / 7$, p. 65, n. 18; CMB I $14=A E$ 1912, 11; CMB I $15=C I L$ II 4714 $=C I L \mathrm{II}^{2} / 7$, p. 66, n. 21; $C M B$ I $16=C I L$ II $4715=C I L \mathrm{II}^{2} / 7$, p. 66, n. 22; Caligula: $C M B$ I $17=$ $C I L$ II $6208=C I L I^{2} / 7$, p. 65 , n. $2=H E p$ 4, 292; $C M B$ I $18=C I L$ II $4717=C I L I^{2} / 7$, p. 65 , n. 14 $=H E p$ 4, 301; $C M B$ I $19=C I L$ II $4716=I L S 193=C I L I^{2} / 7$, p. 66, n. 28; Claudius: $C M B$ I $20=$ $C I L$ II $4718=C I L \mathrm{II}^{2} / 7$, p. 66, n. 29; Nero: $C M B$, I $21=C I L \mathrm{II}^{2} / 7$, p. $54=A E$ 1986, $368=H E p$ 1, 277; $C M B$ I $22=C I L I^{2} / 7$, p. 65, n. $9=H E p$ 5, 315; CMB I $23=C I L$ II $4719=C I L I^{2} / 7$, p. 66, n. 23; from El Puerto de Santa María $C M B$ I $25=C I L$ II $4734=I L S 227$. 


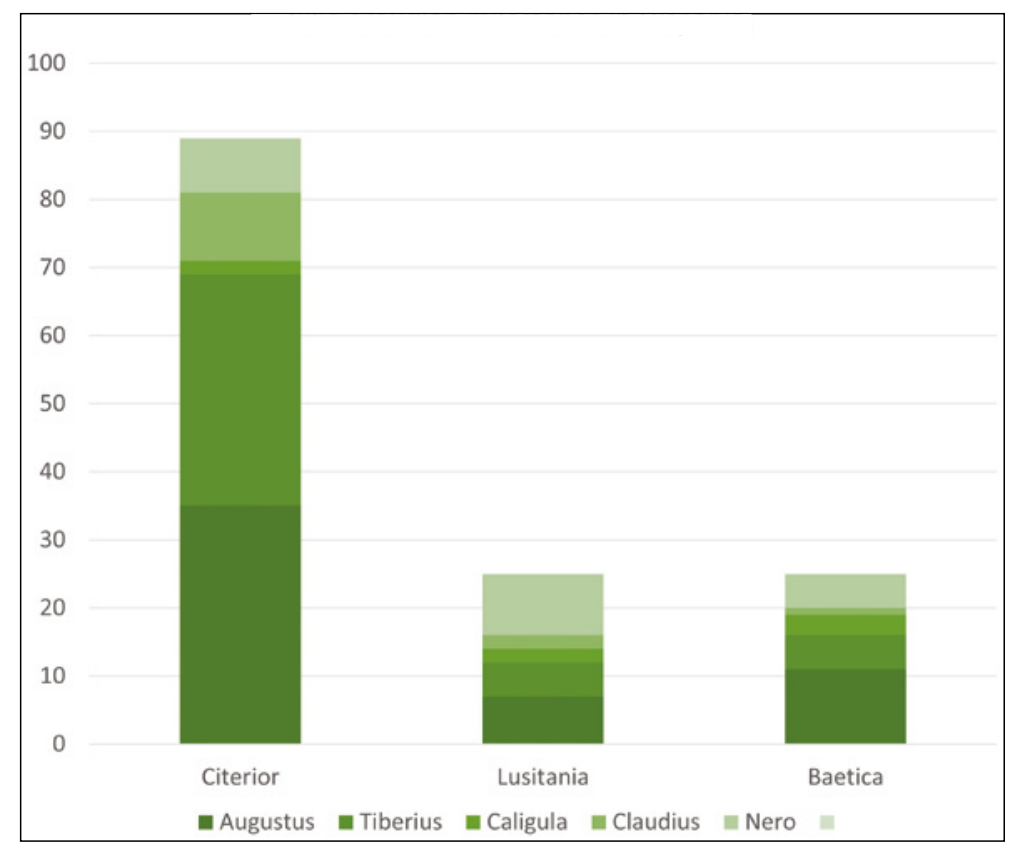

FIGURE 5.1 Julio-Claudian milestones in Hispania SOURCE: AUTHOR

was the only caput for the whole provincial territory in contrast to the via Augusta in Hispania Citerior, which had different intermediate capita viae. This Baetican caput is known as the Ianus Augustus and is an important element of the Baetican geography and a proof of how important roads and road epigraphy were in the geographical conception. The integration process of the already existing road system into the new one, received an impressive image and symbol by the Ianus-orchestration, going thus far beyond the Roman imperial standard of administrative necessities and imperial propaganda. In the Iberian Peninsula, the subdivision of Hispania Ulterior into two parts reformulated the conception of territory and mobility. The former highway called

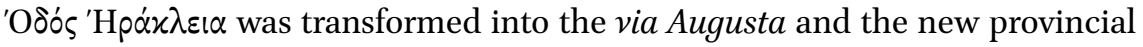
limit between Baetica and Citerior was marked with the previously quoted Ianus Augustus. Apart from the above said symbolic value, it had an important practical function by its role as caput viae.

Augustan milestones inform us about the so-called Ianus Augustus saying that it leads a Baete et Iano Augusto ad Oceanum. ${ }^{33}$ The information can be

33 L.A. Holland, Ianus and the bridge (Rome 1961), 294-295; A. Nünnerich-Asmus, 'Straßen, Brücken und Bögen als Zeichen römischen Herrschaftsanspruchs', in W. Trillmich et al. (eds.), Hispania Antiqua. Denkmäler der Römerzeit (Mainz 1993), 121-157, esp. 134; 
completed with the milestones from Tiberius and Caligula (ab Iano Augusto qui est ad Baetem usque ad Oceanum) and also with those from the Domitian time (ab arcu unde incipit Baetica). ${ }^{34}$ Taking into account all this information, we can imagine that the Ianus Augustus was a monumental arch placed on the border between the two provinces. With the Augustan reorganisation of Hispania, the limit between Citerior and Baetica was definitely fixed at the Baetis river (now called Guadalquivir). ${ }^{35}$ That is why it is often interpreted as being an arch over a bridge, similar to other cases such as Alcántara bridge or Martorell bridge, also in the Iberian Peninsula. ${ }^{36}$ We can also assume that this specific Roman created road landscape including this monumental arch was originally conceived to reach the border to the Oceanum, linking this specific idea with an expression with others from Virgil's Aeneid. ${ }^{37}$ This was a way to persuade the provincial society from this region to develop a new territorial identity in order to transform the previously ethno-geographical idea of Turdetania into a cohesive province. It is also important that sometimes milestones placed on the same road and at the same time have a different text and ordinatio, allowing us to perceive the provincial differences through the different inscriptions of the respective magistrates. This is not only perceivable in the quotation of the Ianus Augustus, but also in the emperor's formulation of his cursus honorum. ${ }^{38} \mathrm{~A}$ quick look at this provincial case can provide us with

P. Sillières, 'Le Ianus Augustus', in R. Bedon and P.M. Martin (eds.), Mélanges Raymond Chevallier: Histoire et Archéologie 1. (Caesarodunum 28, Tours 1994), 305-311, esp. 309. Sillièrs even proposed a temple of imperial cult next to the arch. Remains of a monumental altar have been found and reciently published, J.P. Bellón Ruiz, M.A. Lechuga Chica, M.I, Moreno Padilla, and M. Gutiérrez-Rodríguez, 'Ianus Augustus, Caput Viae (Mengíbar, Spain): an interprovincial monumental border in Roman Hispania', Journal of Roman Archaeology 34 (2021), 3-29. See also my interpretation in S. España-Chamorro, Unde incipit Baetica. Los límites de la Baetica y su integración territorial (s. I-III) (Rome 2021), 195-200.

$34 C I L \mathrm{II}^{2} / 5$, p. 65 , n. $10=C I L \mathrm{II}^{2} / 7$, p. 65 , n. $15=C M B$ I $27 ; C I L$ II $4721=C I L \mathrm{II}^{2} / 7$, p. 66, n. $3 \mathrm{O}=$ $C M B$ I $28 ; C I L$ II $4722=C I L$ II $^{2} / 7$, p. 66, n. $31=C M B$ I 29; $C I L$ II $4703=C M B$ I 3 O.

35 Most researchers have identified two stages of the fixation of the frontier. However, P. Moret, 'La Lusitanie d'Artemidore', Palaehispanica 10 (2010), 113-131 has convincingly questioned this idea. For further analysis see España Chamorro 2017, op. cit. (n. 3), 440-444.

36 C. Fernández Casado, Historia del puente en España: puentes romanos (Madrid 2008), 61-122; 319-334.

37 Verg. Aen. 1.286-288: Nascetur pulchra Troianus origine Caesar, imperium oceano, famam qui terminet astros, Iulius, a magno demissum nomen Iulo.

38 Due to the low number of sources, it is only perceivable in some specific spots. For this question see D. Estefanía, 'Notas para la delimitación de los Conventos Jurídicos en Hispania', Zephyrus 9 (1958), 51-57; P. Sillières, 'Les villes du pouvoir et le réseau des grandes voies romaines de l'Hispanie', Revista de historiografía 25 (2016), 177-189, esp. 186-187; S. España-Chamorro, 'Miliarios y límites provinciales: Algunas reflexiones sobre 
a real idea of how Romans living in the provinces engaged with road inscriptions. The via Augusta was the main road of this province. For this reason, it was also the preferred zone for placing these elements of propaganda. From a total amount of 79 milestones, 46 road inscriptions were placed in this axis of communication, and most importantly, 43 in the surrounding of Corduba, the provincial capital. ${ }^{39}$ In Lusitania, milestones show an interesting pattern. ${ }^{40}$ It is astonishing that no milestones of Augustus have been found near the capital of the province, which was founded by this very emperor as part of his restructuration plan of the Iberian Peninsula. Notwithstanding this centreconnected absence, two Augustan milestones can be found in the main axis of the province (Silver way). ${ }^{41}$ This number is quite low if we compare it to another secondary road that links the important military camp Castra Caecilia with the area of Centum Cellae, but for the Romans there seemed no apparent reason for developing propaganda by putting up inscribed milestones neither in this area nor for this road. The most probable option is that this road continued to Bracara Augusta, in Hispania Citerior, but the area has only recently been explored and the results are still preliminary. ${ }^{42}$ We might think that the four milestones that have been found in this unknown axis of communication once constituted this road. ${ }^{43}$ This area is not important for the province communication because there are no important cities, settlements, quarries or mines. Another Augustan milestone (the only one found in the Algarve) ${ }^{44}$

el miliario de Mengíbar $C I L$ XVII/1, 93 y la frontera oriental entre la Bética y la Citerior', Epigraphica 80 (2018), 211-228.

39 P. Sillières, 'La Via Augusta de Cordoue à Cadix. Documents du XVIII e s. et photographies aériennes pour une étude de topographie historique', Mélanges de la Casa de Velázquez, Madrid 12 (1976), 27-67; S. España-Chamorro, 'El paisaje epigráfico viario de la via Augusta. Consideraciones de la jurisdicción de los conventus iuridici y la epigrafía miliaria', Florentia Illiberritana 28 (2017), 35-55.

40 For a general perspective of Lusitanian roads (but not an accurate corpus of milestones) cf. V. Mantas, 'A rede viária romana em Portugal. Estado da questão e perspectivas futuras', Anas 21-22 (2008-2009), 245-272; V. Mantas, As vias romanas da Lusitânia (Merida 2012). Casar de Cáceres: $C P I L C 677=M V P 74=C I L C$ I 193; Ahigal: $H E p$ 10, $108=H E p$ 14, $78=C R C$ $16=C I L C$ III 920 (previously thought as being a Tiberian one, it is now reinterpreted as an Augustan milestone by E. Paredes Martín, 'Notas sobre la presencia de Augusto en el Iter ab Emerita Asturicam: acerca de dos miliarios de la provincia Lusitania', Studia Historica. Historia Antigua 29 (2021), 253-278.

42 V. Mantas, 'Da capital da Lusitânia a Bracara Augusta pela Serra da Estrela', Conimbriga 58 (2019), 255-300.

43 Coria: $H E p$ 8, 57 = CILC IV 1254; Fuenteguinaldo: $H E p$ 18, $419=A E$ 2012, 729; Alfaiates: $A E$ 1967, 185 = HEp 15, 505; the Argomil: HEp 1, 682 = RAP 479 = HEp 15, 502 'milestone' should be taken with caution, as others have categorised the stone as a terminus, see V. Mantas, 'A política viária de Augusto na Lusitânia', in T. Nogales Basarrate and N. Barrero Martín (eds.), La fundación de Augusta Emerita y los orígenes de Lusitania, (Mérida 2018), 189-221.

Moncarapacho: IRCP 66o, for other scholars this one may date to Claudius. 
comes from Bias do Sul, between Faro and Tavira. Its inscription has been ascribed to Augustus, but the fragmented text raises doubts and could have as well mentioned another Julio-Claudian emperor. As explained earlier, this isolated milestone does not make sense in terms of imperial or Roman provincial propaganda because there is a low density of settlements in this area with no important cities in terms of demography or as concerns a specific interest of provincial administration. Most milestones of Augustus in Lusitania have a quadrangular appearance, unlike the column form Baetica and Citerior. ${ }^{45}$ These Augustan milestones in Lusitania can also be related to the first stelae found in Augusta Emerita (the provincial capital) dated between the last years of the 1st century BCE and the beginning of the 1st CE. ${ }^{46}$

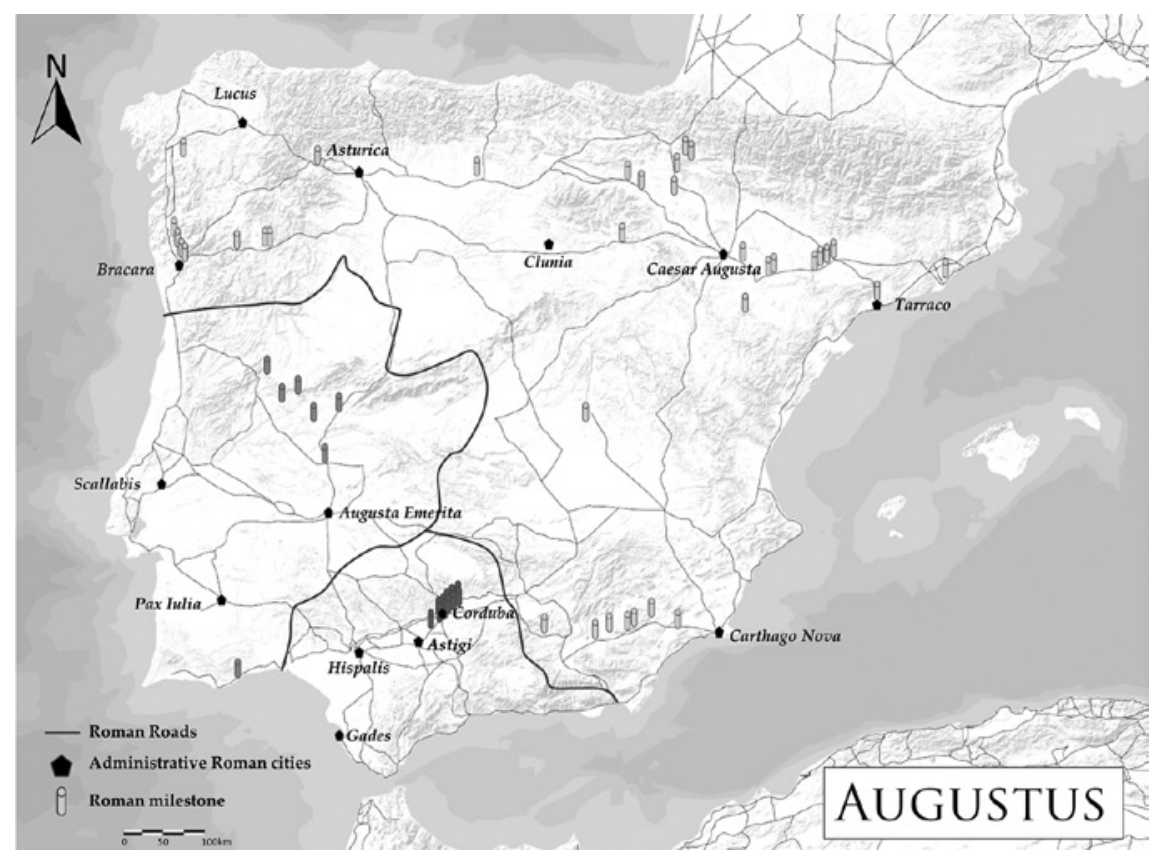

FIGURE 5.2 Milestones of Augustus in the Iberian Peninsula SOURCE: AUTHOR

45 Maybe this corresponds to different moments in the road plan of this province. The older ones could have had a quadrangular form while the newer ones had a column form. We only have some consular chronology for some of the quadrangular milestones that proves an early chronology. For those with a column form we do not have any fixed dates, but maybe they were placed later, coinciding with the earliest Baetican milestones.

46 J. Edmonson, 'Las estelas funerarias marmóreas de Augusta Emerita: novedades, revisiones y apuntes tipológicos, técnicos e iconográficos', Anas 25-26 (2012-2013), 133-171. 


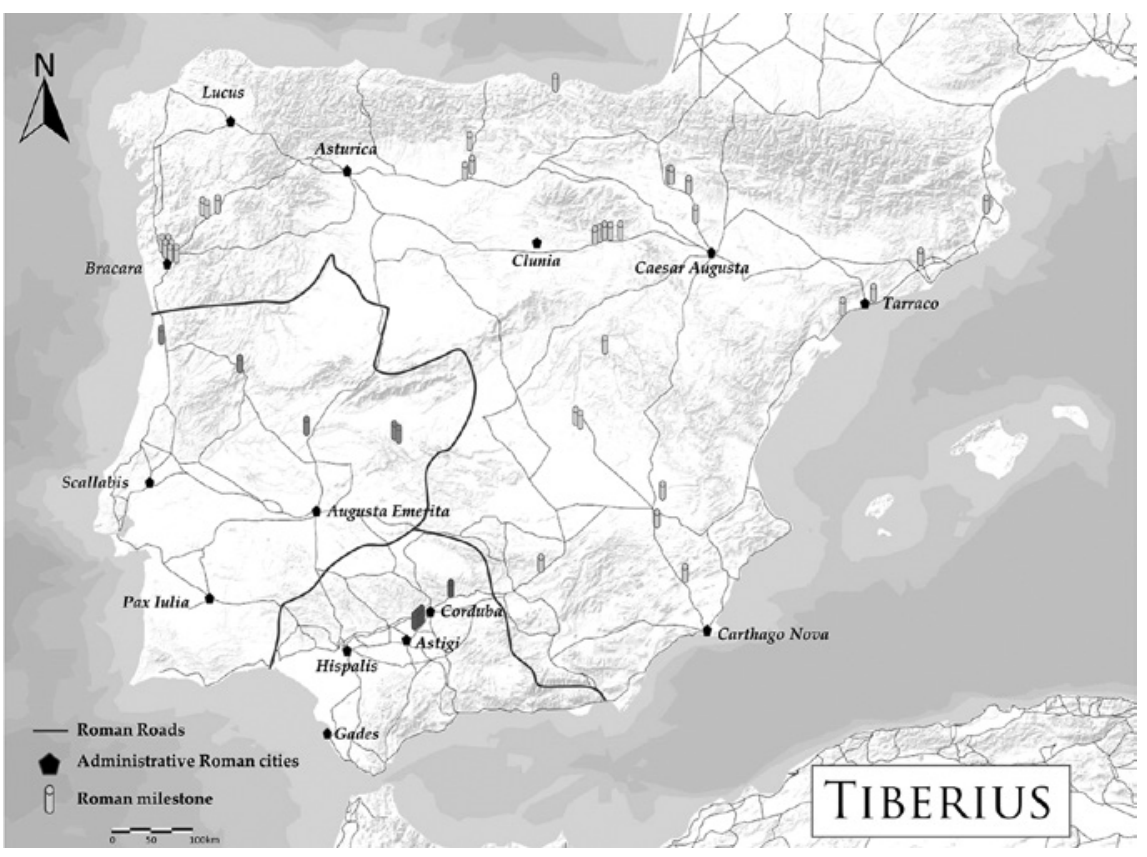

FIGURE 5.3 Milestones of Tiberius in the Iberian Peninsula SOURCE: AUTHOR

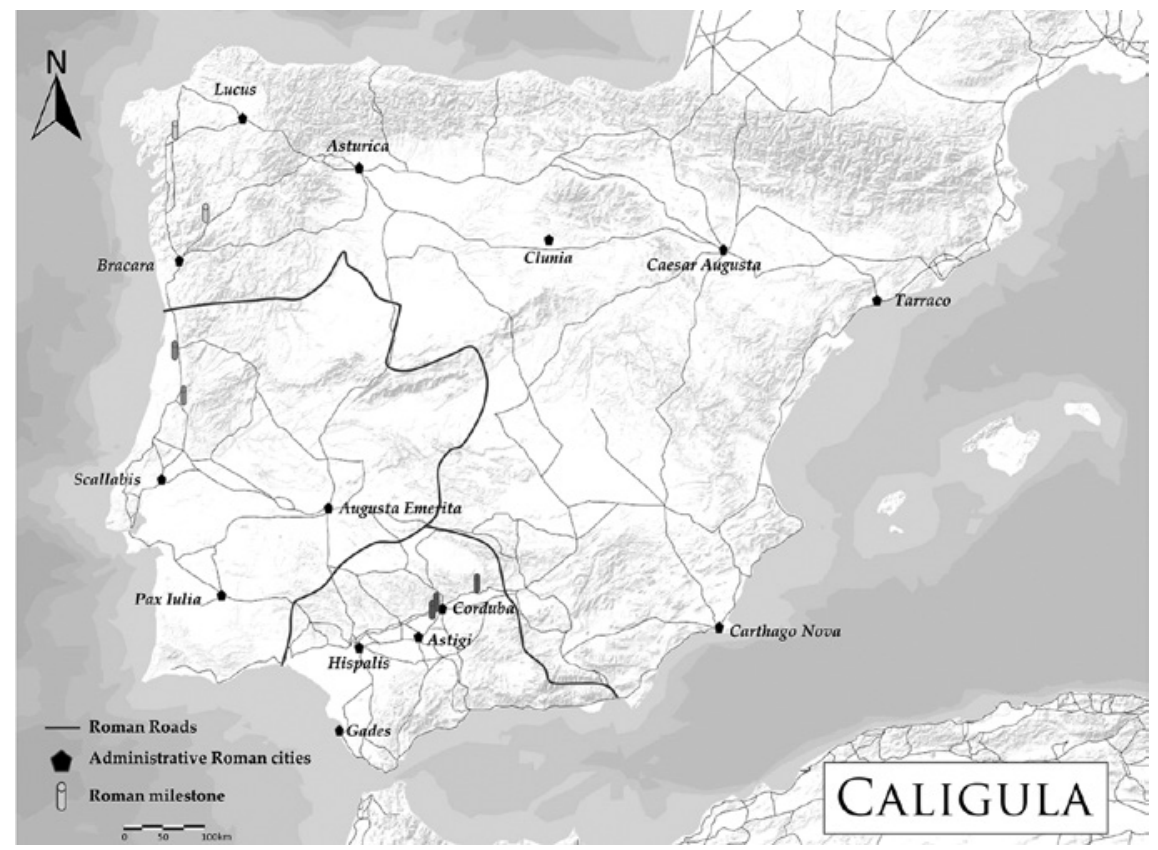

FIGURE 5.4 Milestones of Caligula in the Iberian Peninsula SOURCE: AUTHOR 


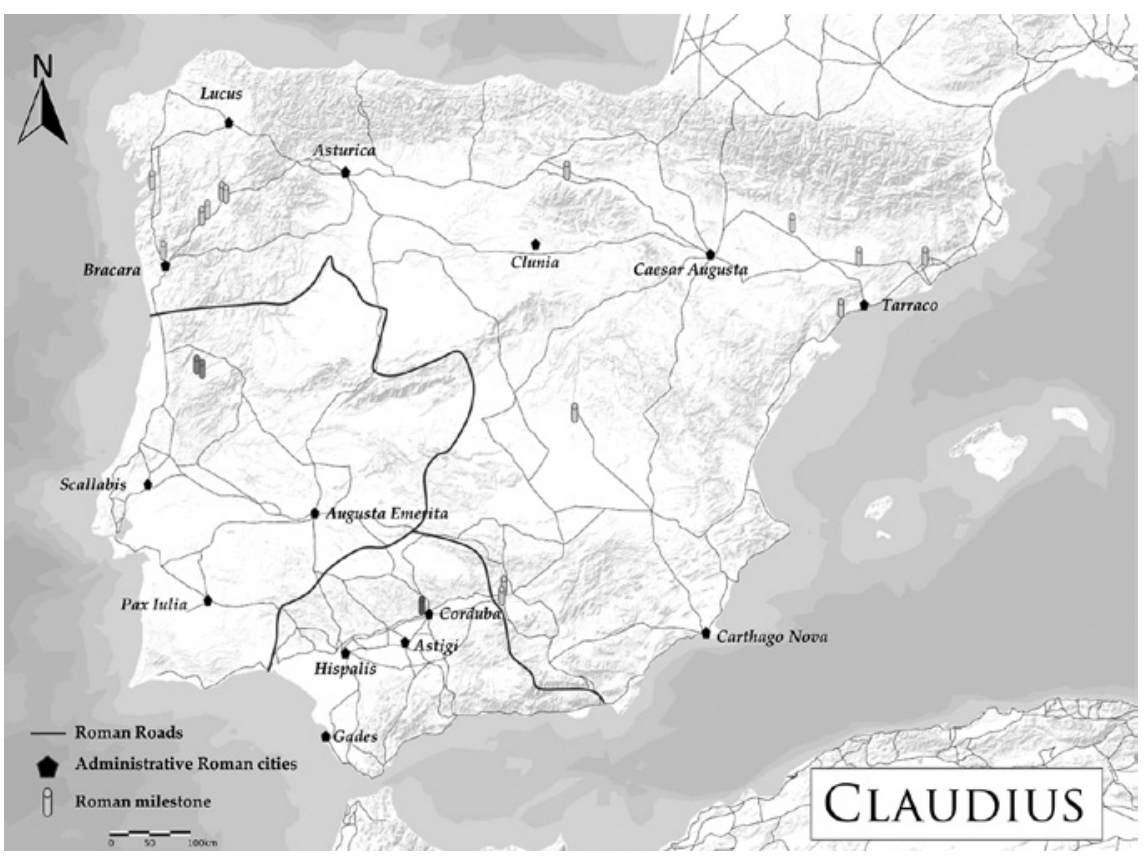

FIGURE 5.5 Milestones of Claudius in the Iberian Peninsula SOURCE: AUTHOR

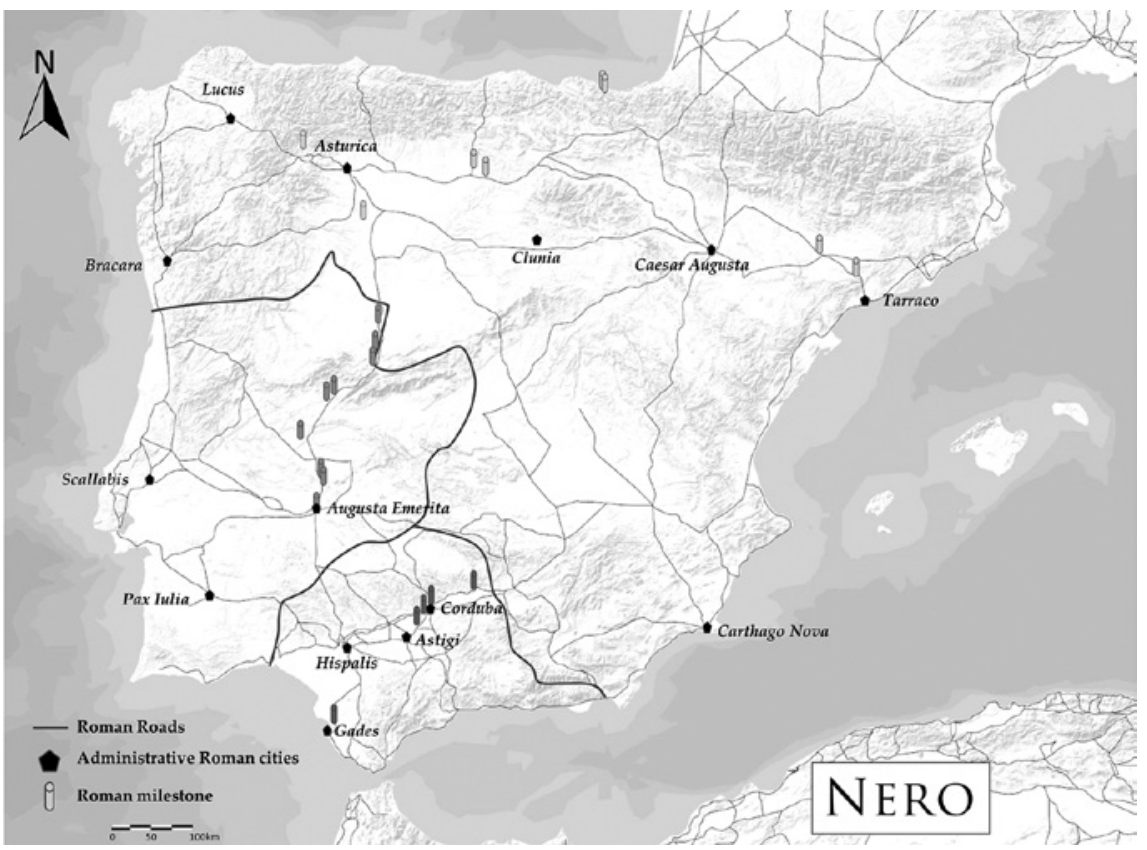

FIGURE 5.6 Milestones of Nero in the Iberian Peninsula SOURCE: AUTHOR 
It is more difficult to get an idea of Tiberius' plan for the infrastructure of Hispania with additions (or changes) to Augustus' conception. If we see the evidence from his reign, we can see that only one appears in the same area of the Augustan inscriptions. ${ }^{47}$ Two more were found in the surroundings of Augustobriga, which was not a main city, but was an important point of connection with Hispania Citerior and cities such as Toletum or Caesaraugusta. ${ }^{48}$ Another isolated milestone was placed in Guarda next to Centum Cellae. ${ }^{49}$ This crossroads could have been an important point of communication, as we saw earlier with the presence of Augustan milestones on the same road. This road is not mentioned in the late antique itinerary sources. This gave rise to the idea that it might have lost its importance after the Julio-Claudian period. Finally, the latest of Tiberius' milestones were placed for the first time between Scallabis and Bracara..$^{50}$ On this important highway, we have also identified two more road inscriptions dated back in the age of Caligula. ${ }^{51}$ The cities Scallabis and Bracara were both capitals of different conventus iuridici (one Lusitanian, the other Citerior). However, this road was not the main axis of the province.

Only two milestones are known from the reign of Claudius. They were found in Viseu, not important as a Roman settlement, but it was a kind of crossing point between the coastal highway and the roads to the interior of the Iberian peninsula. ${ }^{52}$ It is only with emperor Nero, when 9 milestones were placed in the so called Silver Way, in the important part between Augusta Emerita and Salmantica. ${ }^{53}$ With him, a new habit starts taken up by the emperors of the second century. The emperors Trajan and Hadrian will later reinforce and

47 Garrovillas de Alconetar: $C M P C$, p. $5^{2}=E A E 7 \mathrm{O}=$ CILC I 208.

48 Carrascalejo: $C I L$ II $4644=M V P$; Carrascalejo: $C I L$ II $4645=C I L$ II $6200=M V P 5$.

49 Guarda: Ficheiro Epigráfico 42 (1992), $189=A E$ 1992, $943=H E p$ 5, 1025.

50 Oliveira de Azaméis: AE 1967, 131.

51 Coimbra: CIL II 4639; Mealhada: CIL II 4640.

52 F. Campo and C. Viseu in Beira Alta 12 (1955), 49; F. Espinho and C. Manguale in Beira Alta 12 (1955), 54-55.

53 Mérida: $H A E 2056=E R A E$ 6o $=M V P 1=C I I A E$ 86; Alcuéscar: $C I L C$ I $67=H E p$ 16, 65; Casas de Don Antonio: $H E p$ 1, 163 = MVP 34 = CILC I 186; Garrovillas de Alconetar: $C I L$ II 4652 = CPILC $682=$ MVP $89=C I L C$ I 209; Carcaboso: $C I L$ II $4657=C M P C 35=A E$ 1967, $198=$ CPILC 692 = MVP $100=H E p$ 13, 230 = CRC 88 = CILC III 954; Cáparra: $A E, 1967,108=C P I L C$ $699=M V P 109=C R C$ 80 = CILC III 1075; Cáparra: $C I L$ II $4665=C P I L C 707=M V P 114=C R C$ 82 = CILC III 1078; Valverde de Valdelacasa: G. Gillani, M. Santonja and C. Macarro: 'Los miliarios de la Vía de la Plata en la provincia de Salamanca', in G. Gillani, M. Santonja G. Gillani, M. Santonja (eds.), Arqueología en la Vía de la Plata (Salamanca 2007), 114-115; Membibre de la Sierra: MVPSa 43; San Pedro de los Rozados: $C I L$ II $4683=$ CIRPSa $259=$ ERPSa 228. 
renovate this Silver road with $5^{1}$ milestones and anepigraphic columns. ${ }^{54}$ Nero placed the first milestones in the surrounding of Augusta Emerita, the provincial capital. But we find them only in the northern part of this road. In the southern part of this road a couple of anepigraphic milestones have been discovered, but we cannot surely know the date of their were placed. It must be said that we find the anepigraphic objects of this road only in the Lusitanian part. Crossing the border and entering to Baetica, we find ourselves in the socalled Baeturia celtica, an area with its own culture in which the absence of milestones itself is a sign of a regional identity. In general, Julio-Claudian road policy in Lusitania does not follow a coherent pattern, different to what we have observed in Baetica. The Lusitanian evidence is quite scattered and the stones are placed on some secondary axes.

The situation in Hispania Citerior is slightly different. Milestones of Augustus are dispersed in the provincial territory. There are three main areas of positioning:

1. The southern part of the province with the important connection CastuloAcci-Carthago Nova. ${ }^{55}$ This axis of communication was one of the factors to determine the line of division between the former province of Hispania Ulterior and the Hispania Citerior due to the control of the lead, cooper and silver mines of the surroundings of Castulo.

2. An important area is the Ebro valley taking Caesaraugusta (Zaragoza) as the central point. A total of 14 milestones can be found in the roads around Caesaraugusta, mainly the western section (direction to Tarraco) and to the east and north-east (direction to the two main cities of the upper Ebro: the colony of Calagurris, that was placed the northern corridor to the Cantabrian area, not yet completely pacified, and the municipium of Pompaelo, that controlled the road to the province of Aquitania).

3. In the north-western part, milestones are concentrated near Bracara and on the main axis of connection to Lucus and Asturica, capitals of the conventus iuridici of this part of the province.

There is a total absence of road epigraphy on the Citerior via Augusta in the age of the first princeps. It will be the time of Tiberius until we find some milestones on this road, exactly around Tarraco and Barcino and on the connection

5429 from Trajan, 22 from Hadrian; Some notes about Hadrian in E. Paredes Martín, 'La presencia epigráfica de Hadriano en Lusitania: Ciudad y Territorio', Anas 25-26 (2012-13 [2018]), 273-295.

See M. Schmidt, 'Roads and towns along the border of Hispania Citerior', in J. López Vilar (ed.), Tarraco Biennal: Congrés Internacional d'Arqueologia i Món Antic (Tarragona 2013), 291-299; España-Chamorro 2018, op. cit. (n. 37). 
between Carthago Nova and Castulo. Two other milestones dating to the reign of Claudius were placed around Tarraco. However, the total number of inscriptions on the main road of the eastern part of the province is almost anecdotic. In contrast to the situation in Baetica, it seems not to have been important to use inscribed propaganda in the coastal rural areas. Maybe the fact that most of the important cities on this road, such as Barcino, Tarraco, Saguntum, Valentia, Lucentum or Carthago Nova, were important ports, the roads had less importance in this context and the freight transport was mainly by ship and not by cart. There is also another important difference: the Ianus Augustus was the only and therefore outstanding caput viae of the via Augusta in the Baetican part, but there are several and different capita viae in the Citerior part of the via Augusta, as we know from milestones dated to the 2nd and 3 rd centuries. The Baetican caput was also a way to promote the conception of the provincial Roman landscape, but the Citerior capita viae seem to have had only a functional purpose of the measurement of distances.

A road that seems to be important is the axis Caesaraugusta-Pompaelo, a road rebuilt in the age of Augustus and Tiberius. The refurbishment was assigned to the veterans of the three legions that founded Caesaraugusta. These legions were also involved in the construction of other infrastructure, such as the aqueduct of Los Bañales. ${ }^{56}$

Concerning to the road policy, we can notice some interesting points elected as a capita viarum in several cities dispersed in the northern part of the province such as the conventual capitals Bracara, Lucus and Asturica, and other places as Pisoraca, or Segobriga in the centre of the province. It is also interesting to note that it is more likely to find milestones in the area that were conquered more recently than on the roads linking the oldest Roman settlements of the province. From these data we can deduce that there was no systematic plan of increasing the propagation of Roman dominance by milestones and other road connected inscriptions on the most circulated paths, as we can see in Baetica.

The birth and rise of road epigraphy in the Iberian Peninsula can be linked to a new perception of the space, in which the former hodologic vision of Hispania

56 J. Andreu Pintado, 'Una ciudad romana al pie de la vía "Caesar Augusta" - "Pompelo": Los Bañales de Uncastillo', El Nuevo Miliario 12 (2011), 3-14; Andreu Pintado 2012, op. cit. (8), 34-37; I. Moreno Gallo 2009, op. cit. (8), 39-43. 
Ulterior and Citerior was transformed into a cartographical plane. ${ }^{57}$ This developed an abstract conception of provinces in which one takes the name of its capital (Citerior Tarraconensis), the other of the main river (Baetica) and the last one takes its name from the main indigenous population of its territory (Lusitania)..$^{58}$ This rec-conceptionalisation of the Hispanic provinces with its "inscribed infrastructure" included the Latinization of its population and is visible within the Augustan epigraphic revolution.

In the case of Baetica, milestones were used as a promotion of the new administrative territory. This kind of epigraphy was reduced to the specific area of the capital, Corduba. It can be interpreted as an aemulatio of communication within the Italian landscape in which, however, a much higher ratio of milestones per road has been found.

In the other two Hispanic provinces, several factors conditioned the location of road inscriptions. In Lusitania, only in the times of Nero an intensification of setting up milestones on the Silver way can be observed. ${ }^{59}$ There is, apparently, no plan for the road epigraphic landscape and milestones are scarce and dispersed.

Finally, we can assume that there was a different focus in the province of Hispania Citerior, as the via Augusta seems to be not important for propaganda in the rural landscapes of Hispania Citerior. The axis that connected the northwestern corner with the east was the preferential path for this kind of inscribed propaganda of the Roman dominance in the countryside. On the contrary, in the Baetican part of the same via Augusta, this road became the preferred place for the propagandistic strategy of the first emperors. Thus, we can observe different processes in the three Hispanic provinces that show diverse ways of understanding and making use of milestones in provincial territories.

However, the above presented is just a specific aspect of a wider phenomenon. The Roman state pursued a very active and systematic policy by building roads in order to spread its influence in the provinces as a "grand strategy". This started in the new Augustan provinces, but it also continued with some Julio-Claudian emperors in the newly conquered territories such

57 See P. Janni, La mappa e il periplo. Cartografia antica e spazio odologico (Rome 1984); F.J. González Ponce, 'Estrabón, Geografía III.5.2. [C167] y la concepción hodológica del espacio geográfico', Habis 21 (1990), 79-92.

58 P. Moret, 'Artemidoro y la ordenación territorial de Hispania en época republicana', in G. Cruz Andreotti et al. (eds.), Romanización, fronteras y etnias en la Roma antigua: el caso hispano (Vitoria 2012), 425-456, esp. 435.

59 C. Puerta Torres, Los miliarios de la via de la Plata (PhD thesis, Madrid 1995). 
as Narbonensis ${ }^{60}$ or Dalmatia. ${ }^{61}$ Julio-Claudian Hispanic milestones are only one (albeit important) piece of the whole puzzle of imperial propaganda in Hispania and it allows us to perceive the construction and the development of the new system of rule. This is must be put in context, not only with a new epigraphic habit commented above, but also with the new urban system promoted by municipalisation, which was started by Caesar and continued by Augustus. For this, the best proof is the many Roman municipia with Julio-Claudian cognomina dispersed in the three Hispanic provinces.

6o The milestones of the Narbonensis are collected in CIL XVII/2: G. Walser, Corpus Inscriptionum Latinarum XVII/. Miliaria Imperii Romani. Miliaria provinciarum Narbonensis Galliarum Germaniarum (Berlin and New York 1986).

61 Julio-Claudian milestones of roads in Dalmatia: CIL XVII/4, 146. 275. 276. 278. 277. 281. 282. 294. 555 . 